\title{
The German humpback: Internationalization and foreign exchange hedging
}

\author{
Tom Aabo ${ }^{\mathrm{a}, *}$, Rasmus Ploeen ${ }^{\mathrm{b}, 1}$ \\ a Aarhus University, Fuglesangs Allé 4, DK 8210 Aarhus V, Denmark \\ b Grundfos Management A/S, Poul Due Jensens Vej 7, 8850 Bjerringbro, Denmark
}

\section{A R T I C L E I N F O}

\section{Article history:}

Received 6 January 2014

Accepted 22 May 2014

Available online 4 June 2014

\section{JEL classification:}

F23

G32

\section{Keywords:}

Internationalization

Foreign exchange hedging

Diversification

Cash flow matching

Operational flexibility

\begin{abstract}
A B S T R A C T
Previous studies find a monotonic positive relationship between a firm's internationalization and its foreign exchange hedging. We argue that high levels of internationalization can reduce the need for foreign exchange hedging through diversification (e.g. sales to several markets) and operational hedging (matching of cash flows and operational flexibility). We employ multivariate regression analysis and find an inverse U-shape relationship ("humpback") for large listed non-financial German firms. Foreign exchange hedging activity peaks when half of sales (or long-term assets) is outside Europe. We do not find support that diversification or production facilities abroad drive our results. Our paper is the first empirical paper to document an inverse U-shape relationship between internationalization and foreign exchange hedging.
\end{abstract}

(c) 2014 Elsevier B.V. All rights reserved.

\section{Introduction}

Empirical studies identify a monotonic positive relationship between a firm's degree of internationalization $^{2}$ (often measured by a foreign sales ratio) and its use of foreign exchange derivatives (Allayannis and Ofek, 2001; Brown et al., 2003; Guay and Kothari, 2003). This positive relationship

\footnotetext{
* Corresponding author. Tel.: +45 8716 4839; fax: +45 86165394.

E-mail addresses: taa@asb.dk (T. Aabo), rploeen@grundfos.com (R. Ploeen).

1 Tel.: +45 24664639 .

2 The terms internationalization and multinationality is often used interchangeably. Dunning (1973) defines a multinational firm as a firm that has production facilities in more than one country. We use the more broad term internationalization. Vahnle
} 
makes intuitive sense since the direct foreign exchange exposure increases when a firm increases its sales to markets that use a different currency than the currency in the firm's home market (e.g. Choi and Prasad, 1995; Bodnar and Wong, 2003). However, at the same time it makes intuitive sense that for certain (high) levels of internationalization, the need for foreign exchange hedging may decrease due to diversification and operational hedging (matching of cash flows and operational flexibility). This facilitates the potential existence of an inverse U-shape relationship between internationalization and foreign exchange hedging. We empirically test such an existence and the underlying reasons.

Specifically, we investigate the relationship between internationalization and foreign exchange hedging for large German non-financial firms. German firms are especially relevant in this context because (1) Germany is the largest economy in Europe and (2) Germany is an open economy with total exports on par with the U.S. The size of the economy makes our findings economically relevant and the openness of the economy provides a relevant setting for the detection of a potential inverse U-shape relationship. New accounting standards provide us with geographical segment information in the annual reports. We use this information to go beyond a simple export ratio which would not make much sense in a German context due to the use of the Euro by many of Germany's major trading partners (e.g. France, Netherlands, and Italy). We measure internationalization by foreign sales outside Europe (and alternatively by foreign long-term assets outside Europe) and find strong support for an inverse U-shape relationship. In practical terms our findings indicate that large German non-financial firms increase their foreign exchange hedging up to the point where they have approximately half of their sales (or long-term assets) outside Europe. From that point on they tend to decrease their foreign exchange hedging. The inverse $U$-shape relationship is especially important for large firms and is economically significant. Thus, the median (largest) firm in term of size goes from a hedge ratio measured as the notional amount of foreign exchange derivatives divided by total sales of $1 \%(11 \%)$ when the firm has no sales outside Europe to $4 \%$ (33\%) when the firm has half of its sales outside Europe and then again to $2 \%(15 \%)$ when the firm has all its sales outside Europe. Our findings are novel and contribute to the understanding of the relationship between risk management and internationalization at the firm-specific level. To the best of our knowledge, we are the first to show an inverse U-shape relationship between the extent of foreign exchange derivatives usage and internationalization.

Our study is related to Hutson and Laing (2014) who find an inverse relationship between the usage/non-usage of foreign exchange derivatives and foreign subsidiaries (number and location) in a sample of US non-financial firms. Our study distinguishes itself from Hutson and Laing in two important aspects. First, Hutson and Laing use a foreign exchange derivatives usage dummy. This is a crude measure that does not distinguish between e.g. a firm that has entered a single forward contract to offset a specific transaction exposure and a firm that uses foreign exchange derivatives extensively as part of a broader enterprise risk management program. We use a continuous variable to measure the extent of foreign exchange derivative usage. Second, Hutson and Laing investigate the inverse Ushape relationship between foreign exchange derivatives usage and internationalization only in terms of foreign subsidiaries ${ }^{3}$ (foreign sales is a control variable). The number and distribution of foreign subsidiaries are relevant aspects of internationalization but give a partial picture of internationalization and they fail to distinguish between (1) small sales subsidiaries and large production subsidiaries and in this line of reasoning (2) subsidiaries that generate/constitute a minor versus a major part of total sales and long-term assets. We use foreign sales and foreign long-term assets ratios to measure firm-specific internationalization.

At least two arguments exist why an inverse U-shape relationship could exist. First, a firm that is international and sells its products to several markets may reduce foreign exchange risk through diversification following well-established theory (e.g. Markowitz, 1959; Sharpe, 1964; Agmon and Lessard, 1977). Second, a firm may reduce foreign exchange risk through operational hedging. This

and Ivarsson (2014) distinguish between (1) firms that are in a state of internationalization with limited geographical spread and/or coordination and (2) firms that have passed this stage and have become "globalized" with wide geographical spread and coordination of activities. Again, we use the term internationalization and encompass both "internationalized" and "globalized" firms.

${ }^{3}$ Hutson and Laing (2014) use three different measures related to foreign subsidiaries: the number of regions in which the firms has subsidiaries; the number of countries in which the firms has subsidiaries; and the number of foreign subsidiaries. 
can be done (1) by matching foreign revenues with foreign costs in the same currency (e.g. Bodnar and Marston, 2002) or (2) by operational flexibility (e.g. being able to switch production between production facilities in different countries following the reasoning of among others Capel, 1997). We investigate the likely reasons for the observed inverse U-shape relationship but we do not find any indication that the relationship is driven by (1) diversification or (2) the ability through foreign productions facilities to match cash flows or operate flexibly. Instead we argue that the inverse u-shape relationship may be driven by the flexibility of sourcing from foreign suppliers and foreign exchange derivatives supply-side constraints.

The next section provides a brief review of the related literature. Section 3 describes the data and the methodology of our study. Section 4 lists the descriptive statistics and correlations. Section 5 performs the multivariate regression analysis. Finally, we provide our conclusions in Section 6.

\section{Related literature}

Internationalization is most often measured by a foreign sales ratio (e.g. Michel and Shaked, 1984; Sullivan, 1994). Less often is the use of foreign assets ratio (e.g. Grant et al., 1988) and the number of foreign countries/foreign subsidiaries (e.g. Allen and Pantzalis, 1996; Morck and Yeung, 1991). Hodder (1982) shows that when price changes and changes in exchange rates are not perfectly correlated, exchange rate changes pose a significant risk to firms involved in international activities (and to a lesser extent to domestic firms). Bartram et al. (2011) find that firms reduce risk by the use of foreign exchange derivatives. The most important such instrument is forward contracts (Bodnar et al., 2011).

In a perfect market situation (Modigliani and Miller, 1958) such hedging does not add value. However, market imperfections exist. Smith and Stulz (1985) show that hedging can add value by reducing financial distress costs and by reducing taxes if taxes are a convex function of earnings. Furthermore, Smitz and Stulz note that hedging may also be driven by managerial risk aversion. Froot et al. (1993) show that hedging can add value under capital market imperfections. Leland (1998) argue that financial hedging increase debt capacity and thereby reduce taxes. Furthermore, Wang et al. (2003) argue that hedging may be optimal to protect non-diversified shareholders and stakeholders. Allayannis and Weston (2001) find a positive relation between firm value and the use of foreign exchange derivatives.

Empirical studies (e.g. Allayannis and Ofek, 2001; Brown et al., 2003; Guay and Kothari, 2003) identify a monotonic positive relationship between the internationalization of a firm (often measured by a foreign sales ratio) and its use of foreign exchange derivatives. Guay and Kothari (2003) find that the use of derivatives appears to be a small part of the overall risk profile of non-financial firms. Nance et al. (1993) note that one substitute for the use of financial derivatives is an alteration of the debt-equity ratio or a change in operations (e.g. by creating off-setting cash flows in exposed currencies). Such alternative ways of addressing foreign exchange risk ties into the integrated risk management framework of Meulbroek (2002) who lists three tools for risk management: (1) use of financial derivatives, (2) change of capital structure, and (3) change in operations. Geczy et al. (2007) and Pantzalis et al. (2001) find that operational hedging techniques are an important component of firms' overall risk-management activities. Guay and Kothari (2003) suggest that firms may use derivatives primarily to fine-tune an over-all risk management program.

An important aspect of the integrated risk management framework is the setup of the firm's operations. Following well-established theory on the risk-reduction properties of diversification (Markowitz, 1959; Sharpe, 1964), a firm that is more geographically diversified in its operations may be able to reduce part of its exchange rate risk through diversification because "idiosyncratic" exchange rate changes cancel out. Pantzalis et al. (2001) find that the larger the number of countries in which the firm has subsidiaries ("breadth"), the lower the exposure, and the more concentrated the network ("depth"), the higher the exposure. A firm may also engage in operational hedging whether in the form of matching of cash flows or exploitation of operational flexibility. Bodnar and Marston (2002) develop a simple model of exchange rate exposure at the firm-specific level and show how a firm can reduce its exposure by offsetting foreign currency revenues and costs. In a U.K. perspective, Bradley and Moles (2002) find that occasionally or often, more than half of the surveyed firms source inputs in the same currencies as sales are made in order to manage exchange rate risk. Aabo et al. (2010) show 
that import on the aggregate level reduces the need for financial hedging for a sample of medium-sized non-financial firms.

Based on the work of Black and Scholes (1973), Myers (1977) introduces the term real option. Following the line of reasoning of real option theory, Kogut and Kulatilaka (1994) suggest that building an international network of production facilities creates value and reduces risk through the option features of such an international network. In a framework of fluctuating exchange rates, Capel (1997) shows how having production facilities in more than one country creates value and reduces downside risk by letting the firm move production according to the development of exchange rates. In her model, Capel incorporates adjustment costs to reflect the fact that most firms cannot switch production from one country to another without incurring some extra costs (and without experiencing a time lag). The existence of adjustment costs makes the choice of production site path dependent. Thus, an international network of production facilities can have a setup that is more or less "sticky". Rangan (1998) finds that fluctuations in exchange rates trigger shifts in manufacturing and sourcing activities by multinational firms. Generally, operational flexibility reduces the need for financial hedging following the line of reasoning of real option theory (e.g. Aabo and Simkins, 2005; Allen and Pantzalis, 1996; Bartram and Bodnar, 2007; Bartram et al., 2010; Reuer and Leiblein, 2000; Mello et al., 1995). Bodnar et al. (2011) find that the second most important reason. ${ }^{4}$ for not using financial derivatives is that "Exposures are more effectively managed by other means".

\section{Data and methodology}

This study is based on public information from the Orbis database and the 2010 annual reports of German large listed non-financial firms. International Financial Reporting Standards (IFRS) No. 8 published in 2006 requires EU firms to report segment information (mandatory from 2009). The new segment information gives a unique opportunity to go beyond the traditional internationalization measure (foreign sales ratio) and investigate the geographical distribution of foreign sales as well as foreign long-term assets.

The targeted population of firms is the 400 largest listed non-financial firms in Germany. We require the 2010 annual reports to contain detailed information on hedging activity and geographical segments to pursue our analysis. These requirements reduce the number of firms to $202 .{ }^{5}$ We further reduce the ultimate sample by four outliers (three firms with negative equity and a single firm with an abnormal hedge ratio ${ }^{6}$ ). In terms of NACE sectors the 198 firms are distributed as follows (NACE letters in parentheses): 17 primary industry firms $(A+B) ; 100$ manufacturing firms (C); 3 water and energy firms (D+E); 6 construction firms (F); 23 wholesale \& retail trade firms $(G) ; 28$ service firms $(\mathrm{H}+\mathrm{I}+\mathrm{J})$; 11 real estate firms (L); and 10 public work firms (M-U).

We hand-collect data on hedging and internationalization from the 2010 annual reports of these 198 firms. The notional amounts of foreign exchange derivatives usage are measured as end-of-year amounts. We use these amounts as proxies for the extent of foreign exchange hedging. ${ }^{7}$ Using a continuous variable for foreign exchange derivatives usage is superior to binary measures because it allows us to test hypotheses on the determinants of the amount of hedging (Allayannis and Ofek, 2001). We will, however, use a binary measure as a robustness check. Internationalization figures for

\footnotetext{
4 The most important reason for not using financial derivatives is "Insufficient exposure to financial or commodity prices".

5 Our initial sample is the 400 largest, listed, German firms. Approximately 150 of these firms did not provide detailed information on their hedging behavior in their 2010 annual reports. Further approximately 50 firms were removed because of either a short stock market history (=recently listed firms) or thin trading of their stocks.

${ }^{6}$ This firm has a hedge ratio measured as the notional amount of foreign exchange derivatives divided by the total sales of more than $500 \%$ while all other firms have hedge ratios in the range of $0 \%$ to $100 \%$.

7 Foreign exchange derivatives can be used for hedging and speculation. Speculation is widespread (e.g. Stulz, 1996). However, we follow the line of reasoning of other empirical studies and proxy hedging by the notional amount of foreign exchange derivatives usage arguing that the bulk of foreign exchange derivatives is used for hedging (e.g. Bodnar et al., 1998; Allayannis and Ofek, 2001). Investigating a large sample of firms from 47 countries, Bartram et al. (2011) find that the use of derivatives is associated with lower idiosyncratic and systematic risk as well as lower cash flow volatility - thus indicating that foreign exchange derivatives are predominantly used for hedging purposes.
} 
foreign sales are for the year 2010 and internationalization figures for foreign long-term assets are 2010 end-of-year amounts.

Germany uses the Euro which makes a simple foreign sales or foreign long-term assets ratio less relevant in a foreign exchange risk management context. Thus, Germany's largest export partner (France) uses the Euro and most of Germany's other European export partners use the Euro (Netherlands, Austria, Italy, and Belgium). ${ }^{8}$ Ideally we would create a foreign sales and foreign long-term assets ratio based on sales and long-term assets outside the Euro area but data limitations disqualify this first best option because of the character of the information on geographical segments in the annual reports (thus the Euro area is rarely stated as a region). The second best option is to create a foreign sales and foreign long-term assets ratio based on Europe. Thus, our foreign sales and foreign long-term assets ratios measure the degree to which the German firms in our sample have sales and long-term assets outside Europe. This is not a perfect measure of non-Euro sales and long-term assets because our measures implicitly treat the U.K., Switzerland, and Poland as using the Euro.

We investigate two competing hypotheses:

Hypothesis 1. states that the relationship at the firm-specific level between foreign exchange hedging and internationalization is positive and linear.

Hypothesis 2. states that the relationship at the firm-specific level between foreign exchange hedging and internationalization follows an inverse U-shape.

Regression analysis is performed using ordinary least squares regression analysis. The dependent variable is a measure of foreign exchange hedging and the independent variables are measures of internationalization plus relevant control variables. The following equation (with variations) is estimated:

$$
\begin{aligned}
\text { CURRENCY HEDGE }_{\mathrm{i}}= & \mathrm{C}+\lambda_{1} \text { ASSETS }_{\mathrm{i}}+\lambda_{2} \text { EQUITYRATIO }_{\mathrm{i}}+\lambda_{3} \text { CURRENT }_{\mathrm{i}}+\lambda_{4} \text { EBITDA }_{\mathrm{i}} \\
& +\lambda_{5} \text { RD }_{\mathrm{i}}+\lambda_{6} \text { MB }_{\mathrm{i}}+\lambda_{7} \text { DIVERSIFICATION }_{\mathrm{i}}+\lambda_{8} \text { FOREIGN DEBT }_{\mathrm{i}} \\
& +\lambda_{9} \text { FOREIGN SALES }_{\mathrm{i}}+\lambda_{10} \text { FOREIGN SALES }_{\mathrm{i}}^{2} \\
& +\lambda_{9} \text { FOREIGN ASSETS }_{\mathrm{i}}+\lambda_{10} \text { FOREIGN ASSETS }_{\mathrm{i}}^{2} \\
& +\lambda_{11} \text { Sector }_{\mathrm{i}}+\omega_{\mathrm{i}}
\end{aligned}
$$

where CURRENCY HEDGE $E_{i}$ is the logarithm of the sum of the notional amount of foreign exchange derivatives divided by the total sales of the firm times 100 plus 1 . In alternative regressions we use a binary variable coded as 1 if the firms uses foreign exchange derivatives (or foreign debt) and 0 otherwise. ASSETS $i$ is the logarithm of the total assets of the firm. EQUITYRATIO $i$ is the equity of the firm divided by the total assets of the firm. CURRENT $T_{i}$ is the logarithm of the sum of current assets divided by current liabilities plus $1 . E B I T D A_{i}$ is the EBITDA of the firm divided by the total assets of the firm. $R D_{i}$ is the logarithm of the sum of the R\&D expenses divided by the total sales of the firm times 100 plus $1 . M B_{i}$ is the logarithm of the sum of the market value of equity divided by the book value of equity of the firm plus 1 . DIVERSIFICATION ${ }_{i}$ is a dummy coded as 1 if the firm operates in more than one industry and 0 otherwise. FOREIGN DEBT $i$ is a dummy coded as 1 if the firm has debt denominated in foreign currency and 0 otherwise. FOREIGN SALES $S_{i}$ is sales outside Europe divided by the total sales of the firm. FOREIGN ASSETS ${ }_{i}$ is long-term assets outside Europe divided by the total long-term assets of the firm. ${ }^{9}$ Sector $_{i}$ are NACE classification codes A+B, D+E, F, G, H+I+J, L, and M-U respectively (Manufacturing, $\mathrm{C}$, being default) coded as 1 if the firm belongs to the specific sector and 0 otherwise.

\footnotetext{
${ }^{8}$ Germany's main export partners are France (10.2\%), UK (7.0\%), Netherlands (6.9\%), US (6.3\%), Austria (5.6\%), Italy (5.4\%), China (5.1\%), Switzerland (4.7\%), Belgium (4.3\%), and Poland (4.1\%). Source: CIA World Factbook (2012).

${ }^{9}$ We want to measure the geographical distribution of long-term assets. However, data is not uniform across annual reports. Thus, while most firms state the geographical distribution of long-term assets, some firms state total assets instead of longterm assets. Furthermore, the treatment of immaterial long-term assets is not consistent across annual reports with some firms including immaterial long-term assets in their geographical distribution of long-term assets and some firms excluding immaterial long-term assets. Similar problems do not apply to the geographical distribution of sales.
} 
Table 1

Descriptive statistics for sample firms.

\begin{tabular}{|c|c|c|c|c|c|c|}
\hline Variable & Mean & Median & Max. & Min. & Std.dev. & JB \\
\hline Total assets (million USD) & 9906 & 888 & 266,429 & 46 & 33,943 & 8432.5 \\
\hline ASSETS & 7.12 & 6.79 & 12.5 & 3.84 & 1.79 & 27.4 \\
\hline EQUITYRATIO & $38.9 \%$ & $38.6 \%$ & $92.5 \%$ & $0.8 \%$ & $16.3 \%$ & 8.3 \\
\hline Current ratio & 1.73 & 1.54 & 15.78 & 0.10 & 1.32 & $35,175.1$ \\
\hline CURRENT & 0.94 & 0.93 & 2.82 & 0.10 & 0.32 & 339.4 \\
\hline EBITDA & $11.2 \%$ & $11.2 \%$ & $36.2 \%$ & $-25.9 \%$ & $8.2 \%$ & 165.1 \\
\hline $\mathrm{R} \& \mathrm{D}$ costs & $2.1 \%$ & $0.4 \%$ & $23.8 \%$ & $0.0 \%$ & $3.5 \%$ & 929.1 \\
\hline $\mathrm{RD}$ & 0.72 & 0.34 & 3.21 & 0.00 & 0.84 & 26.4 \\
\hline Market-to-book ratio & 1.81 & 1.53 & 12.59 & 0.02 & 1.42 & 2822.9 \\
\hline $\mathrm{MB}$ & 0.94 & 0.93 & 2.61 & 0.02 & 0.41 & 19.7 \\
\hline DIVERSIFICATION & 0.19 & 0.00 & 1.00 & 0.00 & 0.39 & 88.0 \\
\hline FOREIGN DEBT & 0.73 & 1.00 & 1.00 & 0.00 & 0.44 & 43.0 \\
\hline FOREIGN SALES & $21.7 \%$ & $17.0 \%$ & $93.0 \%$ & $0.0 \%$ & $23.0 \%$ & 26.3 \\
\hline FOREIGN ASSETS & $15.9 \%$ & $3.6 \%$ & $93.9 \%$ & $0.0 \%$ & $21.4 \%$ & 85.7 \\
\hline Currency hedging & $8.4 \%$ & $1.8 \%$ & $83.0 \%$ & $0.0 \%$ & $15.2 \%$ & 837.9 \\
\hline CURRENCY HEDGE & 1.30 & 1.02 & 4.43 & 0.00 & 1.34 & 18.9 \\
\hline
\end{tabular}

Note: This table reports descriptive statistics for the 198 sample firms. Variables used in subsequent regression analysis are in capital letters. Total assets is the total assets of the firm measured in million USD. ASSETS is the logarithm of Total assets. EQUITYRATIO is the equity of the firm divided by the total assets of the firm. Current ratio is current assets divided by current liabilities. CURRENT is the logarithm of the sum of current ratio plus 1. EBITDA is EBITDA of the firm divided by the total assets of the firm. $R E D$ costs is the R\&D expenses divided by the total sales of the firm. $R D$ is the logarithm of the sum of ( $R E D$ costs times 100) plus 1 . Market-to-book ratio is the market value of equity divided by the book value of equity of the firm. $M B$ is the logarithm of the sum of market-to-book ratio plus 1.DIVERSIFICATION is a dummy coded as 1 if the firm operates in more than one industry and 0 otherwise. FOREIGN DEBT is a dummy coded as 1 if the firm has debt denominated in foreign currency and 0 otherwise. FOREIGN SALES is the percentage of sales outside Europe. FOREIGN ASSETS is the percentage of long-term assets outside Europe. Currency hedging is the notional amount of foreign exchange derivatives divided by the total sales of the firm. CURRENCY HEDGE is the logarithm of the sum of (Currency hedging times 100) plus 1.

We use logarithmic versions of a range of variables in the equation above because the nonlogarithmic version of the variables are positively skewed. The logarithmic versions of the variables are closer to being normally distributed (Table 1 ).

Our focus is on the relationship between foreign exchange hedging (CURRENCY HEDGE) and the internationalization of the firm (FOREIGN SALES and FOREIGN ASSETS). In accordance with previous literature we include control variables. Specifically, we include size (ASSETS) because financial derivatives usage exhibits economies of scale (e.g. Bodnar et al., 1998; Geczy et al., 2007). We include capital structure (EQUITYRATIO) because hedging becomes more valuable when the firm is leveraged (e.g. Geczy et al., 1997). ${ }^{10}$ Current ratio (CURRENT) and profitability (EBITDA) follow a similar reasoning (e.g. Nance et al., 1993). We include measures of growth options ( $R D$ and $M B$ ) because hedging is more valuable for firms with growth options (e.g. Nance et al., 1993; Guay and Kothari, 2003).

One of the arguments behind a potential inverse U-shape relationship is diversification. However, diversification may take place not only in terms of geography but also in terms of different economic sectors. To control for this we include a dummy for industrial diversification (DIVERSIFICATION). Debt denominated in foreign currency can be used as a hedging instrument (e.g. Aabo, 2006; Clark and Judge, 2009; Graham and Harvey, 2001). To control for such foreign debt usage we include a dummy

\footnotetext{
10 Graham and Rogers (2002) estimate the effect of derivatives use on leverage using a simultaneous equations model and find that derivatives usage has a positive effect on leverage. Thus, the cause-and-effect relationship is far from straightforward. Bartram et al. (2009) more generally question mark the validity of the more simplistic framework taken in most empirical papers on hedging and its determinants. Instead they call for a more extensive research into the interactions between hedging and financial/operational strategies. George and Hwang (2010) show that firms with high financial distress costs choose low leverage and vice versa.
} 
for foreign debt usage (FOREIGN DEBT). ${ }^{11}$ Finally, we include sector dummies because firms in different economic sectors face environments in which the interplay between foreign exchange hedging, diversification and operational hedging may vary (e.g. He and $\mathrm{Ng}, 1998$ ).

\section{Descriptive statistics}

Table 1 reports descriptive statistics for the 198 sample firms. Variables used in subsequent regression analysis are in capital letters.

The mean (median) firm has total assets of 9906 million USD ( 888 million USD), an equity ratio of $38.9 \%$ (38.6\%), a current ratio of 1.73 (1.54), EBITDA divided by total assets of $11.2 \%$ (11.2\%), research and developments costs divided by total sales of $2.1 \%(0.4 \%)$, a market-to-book ratio of 1.81 (1.53), sales outside Europe divided by total sales of $21.7 \%$ (17.0\%), long-term assets outside Europe divided by total long-term assets of $15.9 \%$ (3.6\%), and finally a notional amount of foreign exchange derivatives divided by total sales of $8.4 \%$ (1.8\%). The two dummy variables (DIVERSIFICATION and FOREIGN DEBT) show that $19 \%$ of the firms are in more than one industry and that $73 \%$ of the firms use debt denominated in foreign currency.

The economic scale of foreign exchange hedging is fairly modest as also found in previous studies (e.g. Bodnar and Gebhardt, 1999). Thus, the average (median) firm hedges an amount corresponding to an approximate time horizon of 4-5 (1-2) months ${ }^{12}$ of annual sales outside Europe.

Table 2 reports the relationship between foreign exchange hedging and foreign sales (Panel A) and the relationship between foreign exchange hedging and foreign long-term assets (Panel $B$ ). Foreign sales (Panel A) and foreign long-term assets (Panel $B$ ) are divided into five ranges.

Panel A (foreign sales) as well as Panel B (foreign long-term assets) give an immediate indication of a potential inverse $U$-shape relationship between foreign exchange hedging and internationalization. Table 2 also shows that although firms that do not hedge (non-hedgers) tend not to be international, some highly international firms choose not to hedge foreign exchange rates by using foreign exchange derivatives. Likewise, Table 2 shows that some firms (18) that are not international by our measures choose to hedge. ${ }^{13}$ Table 2 follows a simple univariate framework. Before addressing the question of an inverse U-shape relationship in a multivariate framework, Table 3 reports correlation coefficients for independent variables used in subsequent regression analysis.

Table 3 shows that the foreign sales ratio and the foreign long-term assets ratio are highly correlated (0.62). We are, however, using these two variables as alternatives and generally not in the same equation. Table 3 also shows fairly large correlation coefficients ( 0.49 and 0.34$)$ between our internationalization measures and size. Furthermore, research and development costs seem to be highly correlated (0.46) with foreign sales. Finally, equity ratio and current ratio are also highly correlated (0.51). These high correlations may cause problems with multicollinearity and could bias our results toward insignificant coefficients.

\section{Multivariate regression results}

Table 4 reports results of regression analysis on foreign exchange hedging (dependent variable) and foreign sales etc. (independent variables). Model 1 excludes the foreign sales variables. Model 2 includes the foreign sales variable (linear effect) and shows a significant positive linear relationship

\footnotetext{
11 Ideally we would like to measure the extent of foreign debt usage. However, the information in the annual reports only provides such a measure for a limited number of firms. Thus, we resort to a binary measure.

12 Currency hedging for the average (median) firm is $8.4 \%(1.8 \%)$ of total sales. Foreign sales for the average (median) firm is $21.7 \%$ (17\%) of total sales. Currency hedging/foreign sales for the average (median) firm is 0.39 (0.11) corresponding to 4.6 (1.3) months.

1318 firms use foreign exchange derivatives although these firms are not international by our measures. Three reasons are likely to cause this phenomenon: (1) As noted earlier our measurement of internationalization is not perfect because we implicitly assume that the U.K., Poland, and Switzerland use the Euro. Thus, firms can be seen as not being international by our measures and still be exposed to the Great British Pound, the Polish Zloty, and the Swiss Franc; (2) even domestic firms may be exposed to currency exposure through indirect exposure as argued by Aggarwal and Harper (2010) or through direct exposure via imports; and 3) firms may use foreign exchange derivatives for speculation.
} 
Table 2

Internationalization and foreign exchange hedging for sample firms.

\begin{tabular}{|c|c|c|c|c|c|c|}
\hline \multicolumn{7}{|l|}{ Panel A } \\
\hline & \multicolumn{6}{|c|}{ Foreign sales $(x)$} \\
\hline & $0 \%=x$ & $0 \%<x<25 \%$ & $25 \%<x<50 \%$ & $50 \%<x<75 \%$ & $75 \%<x<100 \%$ & Total \\
\hline \multicolumn{7}{|c|}{ Currency hedging } \\
\hline Mean & $1 \%$ & $6 \%$ & $11 \%$ & $28 \%$ & $4 \%$ & $9 \%$ \\
\hline Median & $0 \%$ & $1 \%$ & $5 \%$ & $23 \%$ & $0 \%$ & $2 \%$ \\
\hline Max. & $28 \%$ & $51 \%$ & $60 \%$ & $83 \%$ & $16 \%$ & $83 \%$ \\
\hline Min. & $0 \%$ & $0 \%$ & $0 \%$ & $0 \%$ & $0 \%$ & $0 \%$ \\
\hline$N$ & 56 & 66 & 47 & 24 & 5 & 198 \\
\hline Non-hedgers & 38 & 27 & 4 & 2 & 2 & 73 \\
\hline Hedgers & 18 & 39 & 43 & 22 & 3 & 125 \\
\hline \multicolumn{7}{|l|}{ Panel B } \\
\hline & \multicolumn{6}{|c|}{ Foreign assets $(y)$} \\
\hline & $0 \%=y$ & $0 \%<y<25 \%$ & $25 \%<y<50 \%$ & $50 \%<y<75 \%$ & $75 \%<y<100 \%$ & Total \\
\hline \multicolumn{7}{|c|}{ Currency hedging } \\
\hline Mean & $3 \%$ & $10 \%$ & $13 \%$ & $21 \%$ & $14 \%$ & $9 \%$ \\
\hline Median & $0 \%$ & $4 \%$ & $5 \%$ & $15 \%$ & $16 \%$ & $2 \%$ \\
\hline Max. & $51 \%$ & $83 \%$ & $83 \%$ & $82 \%$ & $25 \%$ & $83 \%$ \\
\hline Min. & $0 \%$ & $0 \%$ & $0 \%$ & $1 \%$ & $0 \%$ & $0 \%$ \\
\hline$N$ & 84 & 65 & 29 & 16 & 4 & 198 \\
\hline Non-hedgers & 49 & 18 & 5 & 0 & 1 & 73 \\
\hline Hedgers & 35 & 47 & 24 & 16 & 3 & 125 \\
\hline
\end{tabular}

Note: This table reports the relationship between Currency hedging and in Panel A: FOREIGN SALES and in Panel B: FOREIGN ASSETS. FOREIGN SALES and FOREIGN ASSETS are divided into five ranges based on the following percentages: (1) $0 \%$, (2) between $0 \%$ and $25 \%$, (3) between $25 \%$ and $50 \%$, (4) between $50 \%$ and $75 \%$, and (5) between $75 \%$ and $100 \%$. Currency hedging is the notional amount of foreign exchange derivatives divided by the total sales of the firm. FOREIGN SALES is the percentage of sales outside Europe. FOREIGN ASSETS is the percentage of long-term assets outside Europe.

Table 3

Correlation coefficients.

\begin{tabular}{|c|c|c|c|c|c|c|c|c|c|c|}
\hline Variable & (1) & $(2)$ & (3) & $(4)$ & $(5)$ & $(6)$ & (7) & $(8)$ & (9) & $(10)$ \\
\hline ASSETS (1) & 1.00 & -0.27 & -0.04 & -0.21 & 0.11 & 0.03 & 0.26 & 0.22 & 0.34 & 0.49 \\
\hline EQUITYRATIO (2) & -0.27 & 1.00 & 0.21 & 0.51 & 0.15 & -0.05 & -0.13 & 0.01 & 0.09 & 0.02 \\
\hline EBITDA (3) & -0.04 & 0.21 & 1.00 & 0.25 & 0.14 & 0.32 & 0.04 & 0.16 & 0.01 & 0.06 \\
\hline CURRENT (4) & -0.21 & 0.51 & 0.25 & 1.00 & 0.16 & -0.05 & -0.07 & 0.03 & 0.04 & -0.03 \\
\hline $\mathrm{RD}(5)$ & 0.11 & 0.15 & 0.14 & 0.16 & 1.00 & 0.24 & -0.01 & 0.35 & 0.46 & 0.26 \\
\hline $\mathrm{MB}(6)$ & 0.03 & -0.05 & 0.32 & -0.05 & 0.24 & 1.00 & 0.13 & 0.18 & 0.10 & 0.08 \\
\hline DIVERSIFICATION (7) & 0.26 & -0.13 & 0.04 & -0.07 & -0.01 & 0.13 & 1.00 & 0.17 & 0.13 & 0.12 \\
\hline FOREIGN DEBT (8) & 0.22 & 0.01 & 0.16 & 0.03 & 0.35 & 0.18 & 0.17 & 1.00 & 0.38 & 0.36 \\
\hline FOREIGN SALES (9) & 0.34 & 0.09 & 0.01 & 0.04 & 0.46 & 0.10 & 0.13 & 0.38 & 1.00 & 0.62 \\
\hline FOREIGN ASSETS (10) & 0.49 & 0.02 & 0.06 & -0.03 & 0.26 & 0.08 & 0.12 & 0.36 & 0.62 & 1.00 \\
\hline
\end{tabular}

Note: This table reports correlation coefficients for independent variables used in regression analysis for the 198 sample firms. Variables are defined in Table 1.

between foreign sales and foreign exchange hedging in line with the results of previous studies. Model 3 includes the foreign sales variable and the foreign sales variable squared (non-linear effect).

Model 3 shows a significant inverse U-shape relationship between foreign sales and foreign exchange hedging with a turning point of $54 \% .{ }^{14}$ The turning point is the internationalization point (measured by foreign sales) where foreign exchange hedging activity is at its maximum. When the median - median in all other aspects than sales outside Europe - firm has $54 \%$ of its sales outside Europe,

\footnotetext{
14 The turning point of $54 \%$ in Model 3 is calculated by differentiating $3.90 \times$ FOREIGN SALES $-3.63 \times$ FOREIGN SALES ${ }^{2}$ and set it equal to 0 . Thus: $3.90-2 \times 3.63 \times$ FOREIGN SALES $=0<=>$ FOREIGN SALES $=54 \%$.
} 


\section{Table 4}

Regression analysis on foreign exchange hedging and foreign sales.

\begin{tabular}{|c|c|c|c|c|c|}
\hline Variable & $\begin{array}{l}\text { Model } 1 \\
\text { (OLS) }\end{array}$ & $\begin{array}{l}\text { Model } 2 \\
\text { (OLS) }\end{array}$ & $\begin{array}{l}\text { Model } 3 \\
\text { (OLS) }\end{array}$ & $\begin{array}{l}\text { Model } 4 \\
\text { (BINARY) }\end{array}$ & $\begin{array}{l}\text { Model } 5 \\
\text { (BI DEBT) }\end{array}$ \\
\hline Constant & $\begin{array}{l}-1.93^{* * *} \\
(0.0008)\end{array}$ & $\begin{array}{l}-1.88^{* * *} \\
(0.0008)\end{array}$ & $\begin{array}{l}-1.87^{* * *} \\
(0.0007)\end{array}$ & $\begin{array}{l}-4.02^{* * *} \\
(0.0000)\end{array}$ & $\begin{array}{l}-0.98 \\
(0.2489)\end{array}$ \\
\hline ASSETS & $\begin{array}{l}0.37^{* * * *} \\
(0.0000)\end{array}$ & $\begin{array}{l}0.33^{* * *} \\
(0.0000)\end{array}$ & $\begin{array}{l}0.32^{* * *} \\
(0.0000)\end{array}$ & $\begin{array}{l}0.48^{* * * *} \\
(0.0000)\end{array}$ & $\begin{array}{l}0.10 \\
(0.2309)\end{array}$ \\
\hline EQUITYRATIO & $\begin{array}{l}-0.29 \\
(0.6027)\end{array}$ & $\begin{array}{l}-0.57 \\
(0.2962)\end{array}$ & $\begin{array}{l}-0.32 \\
(0.5535)\end{array}$ & $\begin{array}{l}-0.28 \\
(0.7400)\end{array}$ & $\begin{array}{l}0.31 \\
(0.7189)\end{array}$ \\
\hline CURRENT & $\begin{array}{l}0.49^{*} \\
(0.0984)\end{array}$ & $\begin{array}{l}0.61^{* *} \\
(0.0394)\end{array}$ & $\begin{array}{l}0.50^{*} \\
(0.0868)\end{array}$ & $\begin{array}{l}0.42 \\
(0.3411)\end{array}$ & $\begin{array}{l}-0.42 \\
(0.3195)\end{array}$ \\
\hline EBITDA & $\begin{array}{l}-1.17 \\
(0.2602)\end{array}$ & $\begin{array}{l}-0.85 \\
(0.4035)\end{array}$ & $\begin{array}{l}-0.97 \\
(0.3325)\end{array}$ & $\begin{array}{l}0.30 \\
(0.8418)\end{array}$ & $\begin{array}{l}3.05^{*} \\
(0.0653)\end{array}$ \\
\hline $\mathrm{RD}$ & $\begin{array}{l}0.34^{* * * *} \\
(0.0012)\end{array}$ & $\begin{array}{l}0.23^{* * *} \\
(0.0290)\end{array}$ & $\begin{array}{l}0.20^{*} \\
(0.0568)\end{array}$ & $\begin{array}{l}0.16 \\
(0.3446)\end{array}$ & $\begin{array}{l}0.46^{* *} \\
(0.0211)\end{array}$ \\
\hline MB & $\begin{array}{l}0.26 \\
(0.2054)\end{array}$ & $\begin{array}{l}0.25 \\
(0.2070)\end{array}$ & $\begin{array}{l}0.22 \\
(0.2791)\end{array}$ & $\begin{array}{l}0.49 \\
(0.1285)\end{array}$ & $\begin{array}{l}0.23 \\
(0.5099)\end{array}$ \\
\hline DIVERSIFICATION & $\begin{array}{l}0.09 \\
(0.6692)\end{array}$ & $\begin{array}{l}0.02 \\
(0.9128)\end{array}$ & $\begin{array}{l}0.03 \\
(0.8622)\end{array}$ & $\begin{array}{l}0.50 \\
(0.1554)\end{array}$ & $\begin{array}{l}0.68 \\
(0.1010)\end{array}$ \\
\hline FOREIGN DEBT & $\begin{array}{l}0.07 \\
(0.7053)\end{array}$ & $\begin{array}{l}-0.04 \\
(0.8481)\end{array}$ & $\begin{array}{l}-0.15 \\
(0.4439)\end{array}$ & $\begin{array}{l}-0.13 \\
(0.6682)\end{array}$ & \\
\hline FOREIGN SALES & & $\begin{array}{l}1.39^{* * *} \\
(0.0014)\end{array}$ & $\begin{array}{l}3.90^{* * * *} \\
(0.0002)\end{array}$ & $\begin{array}{l}4.70^{* * * *} \\
(0.0033)\end{array}$ & $\begin{array}{l}4.86^{* * *} \\
(0.0018)\end{array}$ \\
\hline FOREIGN SALES ${ }^{2}$ & & & $\begin{array}{l}-3.63^{* * * *} \\
(0.0088)\end{array}$ & $\begin{array}{l}-4.88^{* *} \\
(0.0209)\end{array}$ & $\begin{array}{l}-4.87^{* *} \\
(0.0232)\end{array}$ \\
\hline Sector dummies & Yes & Yes & Yes & Yes & Yes \\
\hline Turning point & & & $54 \%$ & $48 \%$ & $50 \%$ \\
\hline$N$ & 198 & 198 & 198 & 198 & 198 \\
\hline$N=0$ & & & & 73 & 53 \\
\hline$N=1$ & & & & 125 & 145 \\
\hline$R^{2}$ & 0.44 & 0.47 & 0.49 & & \\
\hline Adjusted $R^{2}$ & 0.40 & 0.43 & 0.45 & & \\
\hline F-statistic & 9.69 & 10.23 & 10.36 & & \\
\hline $\operatorname{Prob}(F$-stat. $)$ & 0.0000 & 0.0000 & 0.0000 & & \\
\hline McFadden $R^{2}$ & & & & 0.38 & 0.29 \\
\hline LR-statistic & & & & 99.20 & 66.98 \\
\hline Prob(L-stat.) & & & & 0.0000 & 0.0000 \\
\hline
\end{tabular}

Note: This table reports results of OLS (Models 1-3) and binary probit (Models 4-5) regression analysis on foreign exchange hedging (dependent variable) and foreign sales etc. (independent variables). The dependent variable is CURRENCY HEDGE in Models 1-3, a binary version of CURRENCY HEDGE coded as 1 if the firm uses foreign exchange derivatives and 0 otherwise in Model 4, and FDEBT in Model 5. Turning point is the internationalization point (measured by foreign sales) where foreign exchange hedging is at its maximum. Variables are defined in Table 1.

* Indicates significance at the $10 \%$ level.

${ }^{* *}$ Indicates significance at the $5 \%$ level.

**** Indicates significance at the $1 \%$ level.

Model 3 indicates that such a firm has a currency hedging of $4.5 \%{ }^{15}$ of total sales corresponding to half a month of total sales or one month of foreign sales. The currency hedging values for alternative values of foreign sales are (FOREIGN SALES in parentheses) $0.9 \%(0 \%), 3.1 \%(25 \%), 4.5 \%(50 \%), 3.7 \%$ (75\%), and $1.5 \%(100 \%)$.

We measure currency hedging as the notional amount of foreign exchange derivatives as stated in the annual report divided by the total sales of the firm. However, the notional amount of foreign exchange derivatives is a gross amount and may not appropriately reflect the net hedging of the firm. If

\footnotetext{
15 We insert the median values from Table 1 for ASSETS, EQUITYRATIO, CURRENT, EBITDA, RD, MB, DIVERSIFICATION, AND FOREIGN DEBT into Model 3. We insert 54\% for FOREIGN SALES. We assume that the firm is a manufacturing firm. We get a value for CURRENCY HEDGE of 1.70 in Model 3. We have CURRENCY HEDGE $=\ln ($ currency hedging $\times 100+1)$. We get a value for currency hedging of $4.5 \%$ of total sales. $4.5 \%$ of total sales corresponds to half a month $(4.5 \% \times 12=0.5$ month $)$ of total sales or one month of foreign sales $(4.5 \% / 54 \% \times 12=1.0$ month $)$.
} 
relative differences in gross and net hedging across firms are correlated with our internationalization measures, our results can be biased. In line with Bartram et al. (2011), Model 4 employs a simple binary measure of foreign exchange hedging coded as 1 if the firm uses foreign exchange derivatives (125 firms) and 0 otherwise (73 firms). The results support a significant inverse U-shape relationship. To broaden up the concept of foreign exchange hedging, Model 5 uses a binary measure of foreign debt $^{16}$ usage coded as 1 if the firm has issued debt in foreign currency (145 firms) and 0 otherwise (53 firms). The results show that also in terms of foreign debt usage there seems to be a significant inverse U-shape relationship. As a further robustness test (for the sake of brevity not shown in a table), we create an ordered variable with 0 for the 32 firms that use neither foreign exchange derivatives nor foreign debt, 1 for the 62 firms that use either foreign exchange derivatives or foreign debt, and 2 for the 104 firms that use both foreign exchange derivatives and foreign debt ${ }^{17}$ and find a highly significant (both coefficients at the $1 \%$ level) inverse U-shape relationship.

Table 4 shows a significant inverse U-shape relationship between foreign sales and foreign exchange hedging with turning points between $48 \%$ and $54 \%$. In practical terms, Table 4 indicates that large, listed, German non-financial firms tend to increase their use of foreign exchange derivatives up to the point where they have approximately half of their sales outside Europe. From that point they tend to decrease their use of foreign exchange derivatives.

Across all models related to the use of foreign exchange derivatives (Models 1-4), Table 4 shows that large firms (ASSETS) with a high degree of growth options (measured by either $R D$ or $M B$ ) tend to be more active in terms of foreign exchange hedging than other firms. This is in line with the economies of scale argument and the argument that hedging adds more value in the case of firms with growth options. Empirically this is line with among others Guay and Kothari (2003) who find evidence of increased use of derivatives for larger firms and for firms with greater investment opportunities. In relation to the use of foreign debt, we do not find a significant effect from size. We find no significant and consistent effect on hedging from other control variables.

In Table 4 we measure internationalization in terms of foreign sales. The new accounting information on geographical segment information also facilitates a measurement of internationalization in terms of foreign long-term assets. As previously noted, the correlation coefficient between the two variables is 0.62 (Table 3 ). While it is intuitive that foreign sales create positive cash flows that may be financially hedged by the firm, the situation in relation to foreign assets is more complex. Thus, foreign assets may signify positive cash flows in foreign currency (the firm produces and sells in the foreign market and has a positive net cash flow) or negative cash flows in foreign currency (the firm produces abroad but re-exports to e.g. the home market). With this caveat in mind, Table 5 is a direct replication of Table 4 except that Table 5 measures internationalization in terms of foreign long-term assets (as opposed to foreign sales).

Table 5 supports the inverse U-shape relationship found in Table 4 although with less significance (except for foreign debt) and wider dispersion between the turning points (45-65\%). In Table 5 we only list the coefficients for our internationalization variables. For the sake of brevity the coefficients for the control variables are not listed. The conclusions in regard to these control variables are similar to the conclusions of Table 4.

In Tables 4 and 5 we measure internationalization either in terms of foreign sales (Table 4 ) or in terms of foreign long-term assets (Table 5) outside Europe. If we combine the two measures in the same regressions (linear, squared and/or interacted), we find that the main driver behind the use of foreign exchange derivatives is foreign sales as opposed to foreign long-term assets (for the sake of brevity not reported). However, if we put our binary measure of foreign debt usage as our independent variable in the regressions we find that the foreign long-terms assets drive the use of foreign debt.

\footnotetext{
16 Kedia and Mozumdar (2003) examine the determinants of public debt issuance in ten major currencies by large US firms. They find that firms issue foreign currency debt in order to hedge exchange rate exposures. Keloharju and Niskanen (2001) find that Finnish firms raise foreign debt in order to hedge their foreign exchange exposures. Elliott et al. (2003) analyze a sample of 88 US firms and find that foreign debt is used for hedging purposes and that foreign debt substitutes for the use of derivatives in reducing currency risk. Geczy et al. (1997) support the latter notion.

17104 firms use both foreign debt and foreign exchange derivatives. 41 firms use only foreign debt. 21 firms use only foreign exchange derivatives. 32 firms use neither foreign debt nor foreign exchange derivatives. $104+41+21+32=198$.
} 
Table 5

Regression analysis on foreign exchange hedging and foreign long-term assets.

\begin{tabular}{|c|c|c|c|c|c|}
\hline Variable & $\begin{array}{l}\text { Model } 1 \\
\text { (OLS) }\end{array}$ & $\begin{array}{l}\text { Model } 2 \\
\text { (OLS) }\end{array}$ & $\begin{array}{l}\text { Model } 3 \\
\text { (OLS) }\end{array}$ & $\begin{array}{l}\text { Model } 4 \\
\text { (BINARY) }\end{array}$ & $\begin{array}{l}\text { Model } 5 \\
\text { (BI DEBT) }\end{array}$ \\
\hline Control variables & Yes & Yes & Yes & Yes & Yes \\
\hline FOREIGN ASSETS & & $\begin{array}{l}1.11^{* *} \\
(0.0103)\end{array}$ & $\begin{array}{l}2.31^{* *} \\
(0.0403)\end{array}$ & $\begin{array}{l}3.28^{*} \\
(0.0773)\end{array}$ & $\begin{array}{l}8.26^{* * *} \\
(0.0001)\end{array}$ \\
\hline FOREIGN ASSETS ${ }^{2}$ & & & $\begin{array}{l}-1.77 \\
(0.2461)\end{array}$ & $\begin{array}{l}-3.25 \\
(0.2392)\end{array}$ & $\begin{array}{l}-9.09^{* * *} \\
(0.0015)\end{array}$ \\
\hline Sector dummies & Yes & Yes & Yes & Yes & Yes \\
\hline Turning point & & & $65 \%$ & $50 \%$ & $45 \%$ \\
\hline$N$ & 198 & 198 & 198 & 198 & 198 \\
\hline$N=0$ & & & & 73 & 53 \\
\hline$N=1$ & & & & 125 & 145 \\
\hline$R^{2}$ & 0.44 & 0.46 & 0.47 & & \\
\hline Adjusted $R^{2}$ & 0.40 & 0.42 & 0.42 & & \\
\hline F-statistic & 9.69 & 9.79 & 9.31 & & \\
\hline $\operatorname{Prob}(F$-stat.) & 0.0000 & 0.0000 & 0.0000 & & \\
\hline McFadden $R^{2}$ & & & & 0.36 & 0.33 \\
\hline LR-statistic & & & & 93.89 & 76.24 \\
\hline Prob(L-stat.) & & & & 0.0000 & 0.0000 \\
\hline
\end{tabular}

Note: This table reports results of OLS (Models 1-3) and binary probit (Models 4-5) regression analysis on foreign exchange hedging (dependent variable) and foreign long-term assets etc. (independent variables). The dependent variable is CURRENCY HEDGE in Models 1-3, a binary version of CURRENCY HEDGE coded as 1 if the firm uses foreign exchange derivatives and 0 otherwise in Model 4, and FDEBT in Model 5. Turning point is the internationalization point (measured by foreign sales) where foreign exchange hedging is at its maximum. Variables are defined in Table 1.

* Indicates significance at the $10 \%$ level.

** Indicates significance at the $5 \%$ level.

*** Indicates significance at the $1 \%$ level.

This is in line with Aabo et al. (2014) who find that foreign debt is used primarily to hedge foreign assets and subsidiaries as opposed to foreign sales.

In Table 6 we test the extent to which our conclusions are valid for subsets of our 198 sample firms. We address issues in relation to economic sectors (Models 1-2), size (Models 3-4), and exclusion of highly international firms (Model 5). The models in Table 6 are similar to Model 3 in Table 4 in terms of the variables included.

We control for economic sectors in Table 4 by including economic sector dummies. However, such dummies may not adequately capture more complicated structures. Vahnle and Ivarsson (2014) argue that the globalization processes among manufacturing and service firms differ in many respects. Thus, in Models 1-2 we replicate Model 3 in Table 4 with only the 100 manufacturing firms (Model 1) and only the 72 trade and service firms (Model 2) respectively. ${ }^{18}$ Models 1 and 2 show a significant inverse U-shape relationship and indicate that our results are not driven by specific economic sectors. ${ }^{19}$

Model 3 is restricted to only include the 99 firms that belong to the smallest half (as measured by total assets) of our sample firms. Model 4 is the mirror picture of Model 3 and only includes the 99 largest firms. Models 3-4 show that the significance of the inverse U-shape relationship is primarily driven by the largest firms in our sample. ${ }^{20}$

\footnotetext{
18 The 72 trade and service firms include 23 wholesale \& retail trade firms $(G), 28$ service firms $(H+I+J), 11$ real estate firms (L), and 10 public work firms (M-U). Thus, Models 1-2 do not include the 17 primary industry firms $(A+B)$, the 3 water and energy firms $(\mathrm{D}+\mathrm{E})$ and the 6 construction firms (F).

19 Traditionally one may think of service firms as being less capital intensive than manufacturing firms. However, in the present sample there is no significant difference between the sales to capital ratio between the two groups. Thus, total sales divided by total assets reaches 0.87 on average (median 0.78 ) for the 72 service firms and 0.85 on average (median 0.76 ) for the 100 manufacturing firms.

20 The largest firm in our sample is Volkswagen with 266 billion Euro in total assets (annual report 2010). If we insert the values for Volkswagen in Model 3 in Table 4, the model suggests the following currency hedging values for alternative foreign sales ratios (FOREIGN SALES in parentheses): 11\% (0\%), 24\% (25\%), 33\% (50\%), 28\% (75\%), and 15\% (100\%). Volkswagen has a foreign sales ratio of 0.34 which translates into a suggested currency hedging ratio of $32 \%$. In reality Volkswagen has a nominal foreign
} 
Table 6

Regression analysis on foreign exchange hedging and foreign sales for subsamples.

\begin{tabular}{llllll}
\hline Variable & $\begin{array}{l}\text { Model 1 } \\
\text { (manufacturing firms) }\end{array}$ & $\begin{array}{l}\text { Model 2 } \\
\text { (service firms) }\end{array}$ & $\begin{array}{l}\text { Model 3 } \\
\text { (small firms) }\end{array}$ & $\begin{array}{l}\text { Model 4 } \\
\text { (large firms) }\end{array}$ & $\begin{array}{l}\text { Model 5 } \\
\text { (foreign sales 0-50\%) }\end{array}$ \\
\hline Control variables & Yes & Yes & Yes & Yes & Yes \\
FOREIGN SALES & $5.48^{* * * *}$ & $4.06^{* *}$ & $2.82^{*}$ & $4.55^{* * *}$ & $4.95^{* * *}$ \\
& $(0.0009)$ & $(0.0127)$ & $(0.0656)$ & $(0.0086)$ & $(0.0053)$ \\
FOREIGN SALES & $-5.89^{* * *}$ & $-4.95^{*}$ & -2.69 & $-4.30^{* *}$ & $-7.27^{*}$ \\
& $(0.0049)$ & $(0.0692)$ & $(0.2320)$ & $(0.0456)$ & $(0.0766)$ \\
Sector dummies & No & No & Yes & Yes & Yes \\
Turning point & $46 \%$ & $41 \%$ & $52 \%$ & $53 \%$ & $34 \%$ \\
$N$ & 100 & 72 & 99 & 99 & 169 \\
$R^{2}$ & 0.48 & 0.47 & 0.31 & 0.55 & 0.44 \\
Adjusted $R^{2}$ & 0.42 & 0.39 & 0.18 & 0.46 & 0.37 \\
F-statistic & 8.08 & 5.46 & 2.35 & 5.92 & 6.90 \\
Prob(F-stat.) & 0.0000 & 0.0000 & 0.0065 & 0.0000 & 0.0000 \\
\hline
\end{tabular}

Note: This table reports results of OLS regression analysis on foreign exchange hedging (dependent variable) and foreign sales, etc. (independent variables) on various sub samples. The dependent variable is CURRENCY HEDGE. Model 1 covers the 100 manufacturing firms (C). Model 2 covers the 72 trade and service firms (F, G, H, I, J, L, and M-U). Model 3 (4) covers the 99 firms that belong to the smallest (largest) half of the 198 sample firms as measured by total assets. Model 5 excludes the 29 firms that have foreign sales of more than $50 \%$ of total sales (Table 2 ). The control variables are similar to the ones in Table 4 . Turning point is the internationalization point (measured by foreign assets) where foreign exchange hedging is at its maximum. Variables are defined in Table 1.

* Indicates significance at the $10 \%$ level.

*** Indicates significance at the $5 \%$ level.

*** Indicates significance at the $1 \%$ level.

Finally, Model 5 investigates to which extent the inverse U-shape relationship is solemnly driven by firms to the right of the turning points. Thus, Model 5 excludes the 29 firms (Table 2, 24+5=29) that have foreign sales of more than $50 \%$ of total sales. We choose $50 \%$ of total sales because this is close to the turning points in earlier regressions. We still find a significant inverse U-shape relationship. ${ }^{21}$

Overall, the results in Table 6 show that the significance of an inverse U-shape relationship is fairly robust to the exclusion of certain sample firms. Furthermore, all models without exception show turning points in a "relevant" range between $34 \%$ and $64 \%$ which supports a more general existence of an inverse U-shape relationship. However, the regressions do not indicate to which extent such an inverse U-shape relationship is driven by (1) diversification, (2) matching of cash flows, and/or (3) operational flexibility. We address this question by investigating the variation in hedging magnitudes among the firms that are most likely to hedge by conventional standards and create variables related to diversification, matching, and operational flexibility. We find no indication that the inverse U-shape relationship is driven by geographical diversification or matching/flexibility created by production facilities abroad. If anything, we find that the highly international firms that hedge the most tend to be more diversified both in terms of sales and long-term assets, better matched, and have more foreign assets relative to foreign sales. ${ }^{22}$ The results suggest that - at least for the time horizon relevant

exchange derivatives position (used in cash flow hedges) of 62 billion Euro. Total sales are 126 billion Euro. Thus, Volkswagen has an actual hedge ratio of $50 \%$ of total sales $-18 \%$ points higher than indicated by the model.

21 Dolde and Mishra (2007) argue that firms face two levels of decisions in relation to hedging of foreign exchange exposures - an initial hedging/no hedging decision based on a cost/benefit analysis and a subsequent extent of hedging decision for the subsample of firms that choose to hedge in the first stage. However, two findings indicate that the arguments of Dolde and Mishra are not relevant/valid in the context of large, listed non-financial German firms. First, we find highly international firms that hedge very limited amounts. This is not a rational behavior if the costs of setting up a hedging program are prohibitively high. Thus, among the 29 firms with sales outside Europe exceeding 50\% of total sales (Table 2, 24+5=29), we find 10 firms hedging below $5 \%$ of total sales. Four of these ten firms are non-hedgers but six firms are hedgers. Second, we find no indication that the international non-hedgers have a fixed policy of not hedging. Thus, we take a closer look at the eight non-hedgers (Table 2 , $4+2+2=8$ ) that have more than $25 \%$ of their sales outside Europe. We investigate the annual reports and find no indication of a fixed policy of not using financial derivatives. In fact, some of the firms state that they do sometimes use financial derivatives.

22 Specifically, we investigate the variation in hedging magnitudes among the 29 firms that have more than $50 \%$ of their sales outside Europe (Table 2, $24+5=29$ ). Foreign exchange hedging ranges from $0 \%$ to $83 \%$ in this group of firms (Table 2 ). We use 
for foreign exchange hedging decisions - being diversified and having production facilities abroad does not reduce the relevance of foreign exchange hedging. ${ }^{23}$ Guay and Kothari (2003) also observe increased derivatives use among more geographically diverse firms. However, Kim et al. (2006) find that US firms with manufacturing operations abroad (foreign assets) hedge less than US firms without manufacturing operations abroad but with the same degree of sales abroad.

We find no indication that geographical diversification and production facilities abroad contribute to the inverted U-shape relationship between financial hedging and internationalization. Below we argue that two alternative factors - external sourcing and supply-side constraints - are likely to contribute to the inverted U-shape.

External sourcing may provide a flexibility that foreign production facilities do not. Due to lack of data we have only investigated the operational flexibility and the matching of cash flows arguments from the perspective of the firm's own long-term assets. Thus, while the segment information in the annual reports give us information about the geographical distribution of total sales and long-term assets, the annual reports do not provide a similar geographical distribution of the operational costs. Putting it to the extreme, we may compare two firms that according to the available geographical segment information are completely similar but where Firm A has naturally hedged all its revenues in foreign currency by sourcing from suppliers abroad ${ }^{24}$ and Firm B is fully exposed to fluctuations in foreign currency from its foreign sales because it sources domestically. Kogut and Kulatilaka (1994) argue that an important area not investigated is the potential ability - as seen in the apparel industry - of firms "to write short-term contracts that allow the buying firms to switch suppliers based upon changes in costs and exchange rates". Vahnle and Ivarsson (2014) find global external sourcing to be an important aspect in the internationalization of a sample of large multinational manufacturing firms based in Sweden. External sourcing is likely - at least in the time horizon for which the use of foreign exchange derivatives is used for reducing foreign exchange exposures - to be more flexible than altering production at own production facilities. ${ }^{25}$ Tong and Reuer (2007) argue that practical considerations such as trade restrictions, transportation costs, fixed operating costs, and other switching costs all reduce the value of switching options and impede flexibility.

We implicitly assume that a valid foreign exchange contract is available (supply) at a fair price in a liquid market once a firm wants to hedge (demand) a given foreign exchange exposure. However, markets for certain kind of derivatives may not be fully developed either because of the limited

the information on the geographical distribution of sales and long-term assets in the annual reports and create variables related to diversification (the distribution of sales/long-term assets across three regions - Europe, Americas, and Asia (and Africa); the number of countries and regions stated in the annual reports), matching (the alignment between sales and long-term assets across regions), and operational flexibility (foreign assets compared to foreign sales; the diversification variables above) for these 29 firms. However, when we include the new internationalization variables in a multivariate regression analysis in line with Model 3, Table 4, we find that none of the variables are important in explaining the degree of hedging. The only relevant parameter is size. A univariate approach in which we compare "low-hedgers" (firms that hedge less than 20\%) and "highhedgers" (firms that hedge more than 20\%) among the 29 very international firms shows that the high-hedgers are significantly larger (ASSETS), more diversified both in terms of sales and long-term assets, better matched, and if anything have more foreign assets relative to foreign sales than the low-hedgers.

${ }^{23}$ We implicitly assume that the German firms in our sample use foreign exchange derivatives to hedge economic exposure related to cash flows as opposed to accounting exposures (also often termed translation exposures). A firm that has assets in foreign currency (e.g. in the form of production subsidiaries abroad) may experience changes in equity due to changes in exchange rates when the firm's accounts are consolidated into the firm's own currency. Even though such changes in equity are not cash flow based but only affect the accounts of the firm due to translation from one currency to another, a firm may want to engage in foreign exchange hedging to protect the equity from downward adjustments. Such accounting based financial hedges could bias our results and reasoning. Lins et al. (2011) show that foreign exchange hedging is affected by accounting considerations.

24 On the firm-specific level, import may increase or decrease the need for financial hedging. If a firm has costs in the same currencies as it has revenues, the firm will experience a natural hedge by matching foreign currency costs with foreign currency revenues and a subsequent decrease in its need for financial hedging. However, if a firm has costs in currencies in which it has no revenues, the firm will experience an increase in its exposure and an increase in its need for financial hedging. Whether import increases or decreases the need for financial hedging on an aggregate level is an empirical question. Aabo et al. (2010) find that import reduces the need for financial hedging for a sample of medium-sized Danish non-financial firms.

25 In a survey on Danish firms, Aabo and Simkins (2005) find that firms are much more likely to react to changes in exchange rates by "changing sourcing between suppliers in different countries" than by "establishing production in a country where your company did not have production before" or by "shifting production between production outlets in different countries". 
potential scope of the market or because countries set up restrictions that impede an efficient market. Bartram et al. (2009) find that the size of the local foreign exchange derivatives market is an important factor affecting the use of foreign exchange derivatives. It seems plausible that very international firms on the margin target more "exotic" markets than less international firms and that the more "exotic" markets have less developed local markets for foreign exchange derivatives. ${ }^{26}$

\section{Conclusions}

We argue that diversification and operational hedging (matching of cash flows and operational flexibility) can create an inverse U-shape relationship between the degree of internationalization and the firm's use of foreign exchange derivatives. Empirically, we find such an inverse U-shape relationship in a sample of large listed German non-financial firms. Our findings are robust to alternative definitions of internationalization, alternative measures of hedging, and are not driven by specific economic sectors. Our paper is the first paper to detect an inverse U-shape relationship between internationalization and foreign exchange hedging.

We find no indication that the reduced usage of foreign exchange derivatives among highly international firms as compared to less internationalized firms (=the inverse U-shape) is driven by (1) geographical diversification or (2) matching of cash flows or operational flexibility from the firms' own foreign production facilities. We argue that external sourcing from foreign suppliers and supply-side constraints on foreign exchange derivatives may contribute to the inverse U-shape relationship.

Our findings are based on a sample of large non-financial firms in Germany. Germany is a large international player with highly international firms. Thus, a sample of large non-financial firms in less open economies (e.g. the U.S. and Japan) may not exhibit the same inverse U-shape relationship. Furthermore, Bodnar and Gebhardt (1999) and Marshall (2000) show that firms in different countries vary in terms of the underlying reason for hedging. Thus, whether or not firms in other countries display an inverse U-shape relationship between internationalization and foreign exchange hedging is an avenue for further research.

\section{Acknowledgements}

We thank Anne Adelson, Lisbeth Andersen, Ola Bengtsson, Mikael Bergbrant, Daniel Bradley, Annette Vestergaard Christensen, Jane Moeller Christensen, Daniel Andreas Fischer, Delroy Hunter, Haakan Jankensgaard, Alain Krapl, Carsten Larsen, Sattar Mansi, Rasmus Maarbjerg-Andersen, Christos Pantzalis, Jianping Qi, Abraham Ravid, Anders Haugboelle Thomsen, Mads Ulstrup, seminar participants at Lund University and University of South Florida, participants at the 2012 Aarhus-Kiel Workshop, the 2013 International Risk Management Conference, the 2013 Financial Management Association European Conference, and the 2013 Financial Management Association Annual Meeting for helpful comments and suggestions. Tom Aabo acknowledges financial support from the Tuborg Research Center for Globalization and Firms.

\section{References}

Aabo, T., 2006. The importance of corporate foreign debt in managing exchange rate exposure in non-financial companies. Eur. Financial Manage. 12, 633-649.

Aabo, T., Simkins, B., 2005. Interaction between real options and financial hedging: fact or fiction in managerial decision-making. Rev. Financial Econ. 14, 353-369.

Aabo, T., Hoeg, E., Kuhn, J., 2010. Integrated foreign exchange risk management: the role of import in medium-sized, manufacturing firms. J. Multinational Financial Manage. 20, 235-250.

Aabo, T., Hansen, M.A., Muradoglu, Y.G., 2014. Foreign debt usage in non-financial firms: a horse race between operating and accounting exposure hedging. Eur. Financial Manage., http://dx.doi.org/10.1111/j.1468-036X.2013.12032.x (forthcoming).

Aggarwal, R., Harper, J.T., 2010. Foreign exchange exposure of domestic corporations. J. Int. Money Finance 29, $1619-1636$.

\footnotetext{
${ }^{26}$ In a comparison between low-hedgers and high-hedgers among the 29 highly international firm we find that the lowhedgers sell proportionately more to Asia (and Africa) and that the high-hedgers sell proportionately more to Americas. The U.S. is the largest market in Americas and China is the largest market in Asia (and Africa).
} 
Agmon, T., Lessard, D.R., 1977. Investor recognition of corporate international diversification. J. Finance 32, 1049-1055.

Allayannis, G., Ofek, E., 2001. Exchange-rate exposure, hedging and the use of foreign currency derivatives. J. Int. Money Finance 20, 273-296.

Allayannis, G., Weston, J.P., 2001. The use of foreign currency derivatives and firm market value. Rev. Financial Stud. 14, 243-276.

Allen, L., Pantzalis, C., 1996. Valuation of the operating flexibility of multinational corporations. J. Int. Bus. Stud. 27, 633-653.

Bartram, S., Bodnar, G., 2007. The exchange rate exposure puzzle. Manage. Finance 33, 642-666.

Bartram, S.M., Brown, G.W., Fehle, F.R., 2009. International evidence on financial derivatives usage. Financial Manage. 38, $185-206$.

Bartram, S., Brown, G., Minton, B., 2010. Resolving the exposure puzzle: the many facets of exchange rate exposure. J. Financial Econ. 95, 148-173.

Bartram, S., Brown, G., Conrad, J.S., 2011. The effects of derivatives on firm risk and value. J. Financial Quant. Anal. 46, 967-999.

Black, F., Scholes, M., 1973. The pricing of options and corporate liabilities. J. Pol. Econ. 81, 637-654.

Bodnar, G.M., Gebhardt, G., 1999. Derivatives usage in risk management by U.S. and German non-financial firms: a comparative survey. J. Int. Financial Manage. Account. 10, 153-187.

Bodnar, G., Marston, R., 2002. Exchange rate exposure: a simple model. Int. Finance Rev. 3, 107-115.

Bodnar, G.M., Wong, M.H.F., 2003. Estimating exchange rate exposures: issues in model structure. Financial Manage. 32, $35-67$.

Bodnar, G.M., Hayt, G.S., Marston, R.C., 1998. Wharton survey of financial risk management by US non-financial firms. Financial Manage. 27, 70-91.

Bodnar, G., Giambona, E., Graham, J., Harvey, C., Marston, R., 2011. Managing risk management. In: AFA 2012 Chicago Meetings Paper, Available at SSRN: http://ssrn.com/abstract=1787144

Bradley, K., Moles, P., 2002. Managing strategic exchange rate exposures: evidence from UK firms. Manage. Finance 28, $28-42$.

Brown, G., Crabb, C., Haushalter, D., 2003. Are firms successful at selective hedging? J. Bus. 79, 2925-2949.

Capel, J., 1997. A real options approach to economic exposure management. J. Int. Financial Manage. Acc. 8, 87-113.

Choi, J.J., Prasad, A.M., 1995. Exchange risk sensitivity and its determinants: a firm and industry analysis of US multinationals. Financial Manage. 24, 77-88.

Clark, E., Judge, A., 2009. Foreign currency derivatives versus foreign currency debt and the hedging premium. Eur. Financial Manage. 15, 606-642.

Dolde, W., Mishra, D.R., 2007. Firm complexity and FX derivatives use. Quart. J. Bus. Econ. 46, 3-22.

Dunning, J.H., 1973. The determinants of international production. Oxford Econ. Papers 25, 289-336.

Elliott, W.B., Huffman, S.P., Makar, S.D., 2003. Foreign-denominated debt and foreign currency derivatives: complements or substitutes in hedging foreign currency risk? J. Multinational Financial Manage. 13, 123-139.

Froot, K., Scharstein, D., Stein, J., 1993. Risk management: coordinating corporate investment and financing policies. J. Finance 48, 1629-1648.

Geczy, C., Minton, B., Schrand, C., 1997. Why firms use currency derivatives. J. Finance 52, 1323-1354.

Geczy, C., Minton, B., Schrand, C., 2007. Taking a view: corporate speculation, governance, and compensation. J. Finance 62, $2405-2443$.

George, T.J., Hwang, C., 2010. A resolution of the distress risk and leverage puzzles in the cross section of stock returns. J. Financial Econ. 96, 56-79.

Graham, J.R., Harvey, C.R., 2001. The theory and practice of corporate finance: evidence from the field. J. Financial Econ. 60, $187-243$.

Graham, J.R., Rogers, D.A., 2002. Is corporate hedging consistent with value maximization? J. Finance 57, 815-840.

Grant, R.M., Jammine, A.P., Thomas, H., 1988. Diversity, diversification, and profitability among British manufacturing companies, 1972-1984. Acad. Manage. J. 31, 771-801.

Guay, W., Kothari, S., 2003. How much do firms hedge with derivatives? J. Financial Econ. 70, 423-461.

He, J., Ng, L., 1998. The foreign exchange exposure of Japanese multinational corporations. J. Finance 53, $733-753$.

Hodder, J.E., 1982. Exposure to exchange rate movements. J. Int. Econ. 13, 375-386.

Hutson, E., Laing, E., 2014. Foreign exchange exposure and multinationality. J. Bank. Finance 43, 97-113.

Kedia, S., Mozumdar, A., 2003. Foreign currency-denominated debt: an empirical examination. J. Bus. 76, 521-546.

Keloharju, M., Niskanen, M., 2001. Why do firms raise foreign currency denominated debt? Evidence from Finland. Eur. Financial Manage. 7, 481-496.

Kim, Y.S., Mathur, I., Nam, J., 2006. Is operational hedging a substitute for or a complement to financial hedging. J. Corp. Finance $12,834-853$.

Kogut, B., Kulatilaka, N., 1994. Operating flexibility, global manufacturing, and the option value of a multinational network. Manage. Sci. 40, 123-139.

Leland, H.E., 1998. Agency cost, risk management and capital structure. J. Finance 53, 1213-1243.

Lins, K.V., Servaes, H., Tamayo, A., 2011. Does fair value reporting affect risk management? International survey evidence. Financial Manage. 40, 525-551.

Markowitz, H.M., 1959. Portfolio Selection: Efficient Diversification of Investments. John Wiley \& Sons, New York.

Marshall, A.P., 2000. Foreign exchange risk management in UK, USA and Asia Pacific multinational companies. J. Multinational Financial Manage. 10, 185-211.

Mello, A., Parsons, J., Triantis, A., 1995. An integrated model of multinational flexibility and financial hedging. J. Int. Econ. 39, 27-51.

Meulbroek, L.K., 2002. A senior manager's guide to integrated risk management. J. Appl. Corp. Finance 14, 56-70.

Michel, A., Shaked, I., 1984. Does business diversification affect performance? Financial Manage. 13, 18-25.

Modigliani, F., Miller, M., 1958. The cost of capital, corporation finance and the theory of investment. Am. Econ. Rev. 48, $261-297$.

Morck, R., Yeung, B., 1991. Why investors value multinationality. J. Bus. 64, 165-187.

Myers, S., 1977. Determinants of corporate borrowing. J. Financial Econ. 5, 147-176.

Nance, D.R., Smith, C.W.Jr., Smithson, C.W., 1993. On the determinants of corporate hedging. J. Finance 48, $267-284$.

Pantzalis, C., Simkins, B., Laux, P., 2001. Operational hedges and the foreign exchange exposure of US multinational corporations. J. Int. Bus. Stud. 32, 793-812. 
Rangan, S., 1998. Do multinationals operate flexibly? Theory and evidence. J. Int. Bus. Stud. 29, 217-247.

Reuer, J.J., Leiblein, M.J., 2000. Downside risk implications of multinationality and international joint ventures. Acad. Manage. J. 43, 203-214.

Sharpe, W.F., 1964. Capital asset prices: a theory of market equilibrium under conditions of risk. J. Finance 19, 425-442.

Smith, C., Stulz, R., 1985. The determinants of firms' hedging policies. J. Financial Quant. Anal. 28, 391-405.

Stulz, R., 1996. Rethinking risk management. J. Appl. Corp. Finance 9, 8-24.

Sullivan, D., 1994. Measuring the degree of internationalization of a firm. J. Int. Bus. Stud. 25, 325-342.

Tong, T.W., Reuer, J.J., 2007. Real options in multinational corporations: organizational challenges and risk implications. J. Int. Bus. Stud. 38, 215-230.

Vahnle, J., Ivarsson, I., 2014. The globalization of Swedish MNEs: Empirical evidence and theoretical explanations. J. Int. Bus. Stud. 45, 227-247.

Wang, H., Barney, J.B., Reuer, J.J., 2003. Stimulating firm-specific investment through risk management. Long Range Plann. 36 , 49-59. 